\title{
RECONSTRUCTION OF THE DEVELOPMENT HISTORY OF KARSTIC WATER NETWORKS ON THE SOUTHERN PART OF THE GÖMÖR-TORNA KARST ON THE BASIS OF RUINED CAVES AND LANDFORMS
}

\begin{abstract}
REKONSTRUKCIJA RAZVOJA REČNE MREŽE V JUŽNEM DELU KRASA GÖMÖR-TORNA NA PODLAGI PORUŠENIH JAM IN POVRŠINSKIH OBLIK
\end{abstract}

JÁNOS MÓGA ${ }^{1}$

${ }^{1}$ Eötvös Loránd University, Geography Department, Markó u. 29-31, HU-1055 BUDAPEST, HUNGARY

Prejeto / received: 28. 7. 1999 
UDK: 556.3(437.6+439)

\section{János Móga: Rekonstrukcija razvoja rečne mreže v južnem delu krasa Gömör-Torna na podlagi} porušenih jam in površinskih oblik

Avtor razlaga razvoj kraškega površja Gömör-Torna² (na madžarsko-slovaški meji) od terciarja do danes. Na planoti je mogoče slediti razvoju od pokritega do odprtega (golega) krasa in vpliv procesov zakrasevanja na površinske oblike in na smer podzemeljskega odtoka. Avtor je preučil razvoj površja in podzemeljske vodne mreže ter na podlagi morfoloških oblik, ki jih je izdelala voda, ugotovil enakomerno zniževanje vodnih tokov. Opirajoč se na skromne ostanke epigenih dolin, ki so bile tako v sedimentnem pokrovu kot v samem apnencu, na sledi nekdanjih ponorov $\mathrm{v}$ dnu dolin in na opuščene podzemeljske prevodnike (jame) iz zgodnejših faz razvoja, je avtor rekonstruiral smeri odtoka z obravnavanega pokritega krasa.

Ključne besede: geomorfologija krasa, razvoj površja, kraška rečna mreža, Gömör-Torna kras, silicki kras, agteleški kras, Madžarska, Slovaška.

\section{Abstract}

UDC: 556.3(437.6+439)

János Móga: Reconstruction of the development history of karstic water networks on the southern part of the Gömör-Torna karst on the basis of ruined caves and landforms

The author demonstrates the surface development of the Gömör-Torna karst ${ }^{2}$ situated on the HungarianSlovakian border from the Tertiary until the present day. He follows the process of transition from the covered karst conditions to the open karst on the karst plateau, and its effect upon the landforms and the karstic water network. He studied the evolution of surface and sub-surface water networks, and the regularity of the movements of underground rivers based on water tracing. He reconstructed the ancient surface outflow directions of the covered karst from the scarce remains of the epigenetic valleys inherited from cover deposits onto the limestone surface, from ruined swallow hole lines in valleys, as well as from decaying water conducting tubes generated in earlier phases.

Key words: development history, karstic water network, Gömör-Torna karst, Szilice karst plateau, Aggtelek karst, Hungary, Slovakia.

\footnotetext{
${ }^{2}$ The Hungarian side is referred to as the Aggtelek karst, while the Slovakian side is called Slovakian karst.
} 


\section{INTRODUCTION}

Most of the allogenic karst of the Carpathians and the Carpathian basin was buried during the Tertiary, and everywhere on top of the cover deposits of the covered or partly covered karst permanent or periodical water flows were formed which gave birth to valley networks. The karstic cover layers were cut through after a time by these water flows and with this process the inheritance of the water and valley network from the non-karstic cover layer into karstic rocks began.

The inheritance process of the water, and valley network from non-karstic territory into karstic rock surface on the Hungarian karst was first studied by Jakucs $(1956,1968)$ and Hevesi (1984, 1986). According to L. Jakucs $(1956,1968,1971,1977)$ if, in the beginning of the hereditary process when the bed of the water flow reaches the karstified rocks, the karst water table during the larger part of the year is situated directly close to the river bed, the hereditary water flow continues its cutting down through river beds and valleys on karstified rocks as well. In such cases bathycapture cannot occur. If the rise of the land is faster than the cutting down, the deepening of the river bed cannot follow the sinking of the karst water table, and a continuous crack network already widened through solution can be found in the karstified rocks, the water flow is bathycaptured through a swallow hole, the continual formation of its valley through water flow becomes temporary and can cease altogether.

With the deepening and backward erosion of the valley, newer and newer swallow holes are formed in the upper section of the valley. Following this process the lower, to some extent older, swallow holes become periodic, are filled in and in some cases are entirely blocked up, their continual formation is directed mainly by karstic corrosion. These deepenings originating from swallow holes, but functioning only periodically are the swallow hole dolines, which are situated in a row in the axis of the hereditary valleys (series of dolines). The series of dolines on the bottom of the valleys, the old swallow holes and the ruined caves are remnants of the earlier water network. On the GömörTorna karst I reconstructed the ancient surface outflow directions of the covered karst from the scarce remains of the epigenetic valleys inherited from cover deposits unto the limestone surface from series of dolines, as well as from ruined caves and from other landforms.

\section{THE EVOLUTION HISTORY OF THE SOUTHERN PART OF THE GÖMÖR-TORNA KARST BETWEEN THE PANNONIC AND THE END OF THE PLIOCENE PERIOD}

During the Pannonic period the Gömör-Torna karst was a coherent territory only slightly dissected and slanting in between the Slovenské Rudohorie mountains and the Pannon basin. The rivers from the Slovenské Rudohorie ran through the territory of the limestone zone, clipping off, levelling its surface and covering the karstic rocks. The typical levelled surface of the karst region (formed through pediplanation) originate from this period (Mazur 1973, Jakál 1975). The levelled surface of the Pannonian rose in a fan-like form due to the structural movements starting in the UpperPannonian and continuing during the Pontian (Attic, Rhodanian) period. As the rising originated from the northern part of the karst territory and gradually moved towards the $S$, the northern part of the Pelsőc plateau rose highest. 
The folded vaults which split due to tectonic action also produced favourable circumstances for the development of valleys. On the surface of the E-W oriented anticline zones built up from sandstone and clay slate, the final borders of the developing karst plateau were formed by rapidly incising valleys, attracting to themselves the surface and later also the underground water system of the mainly covered karst.

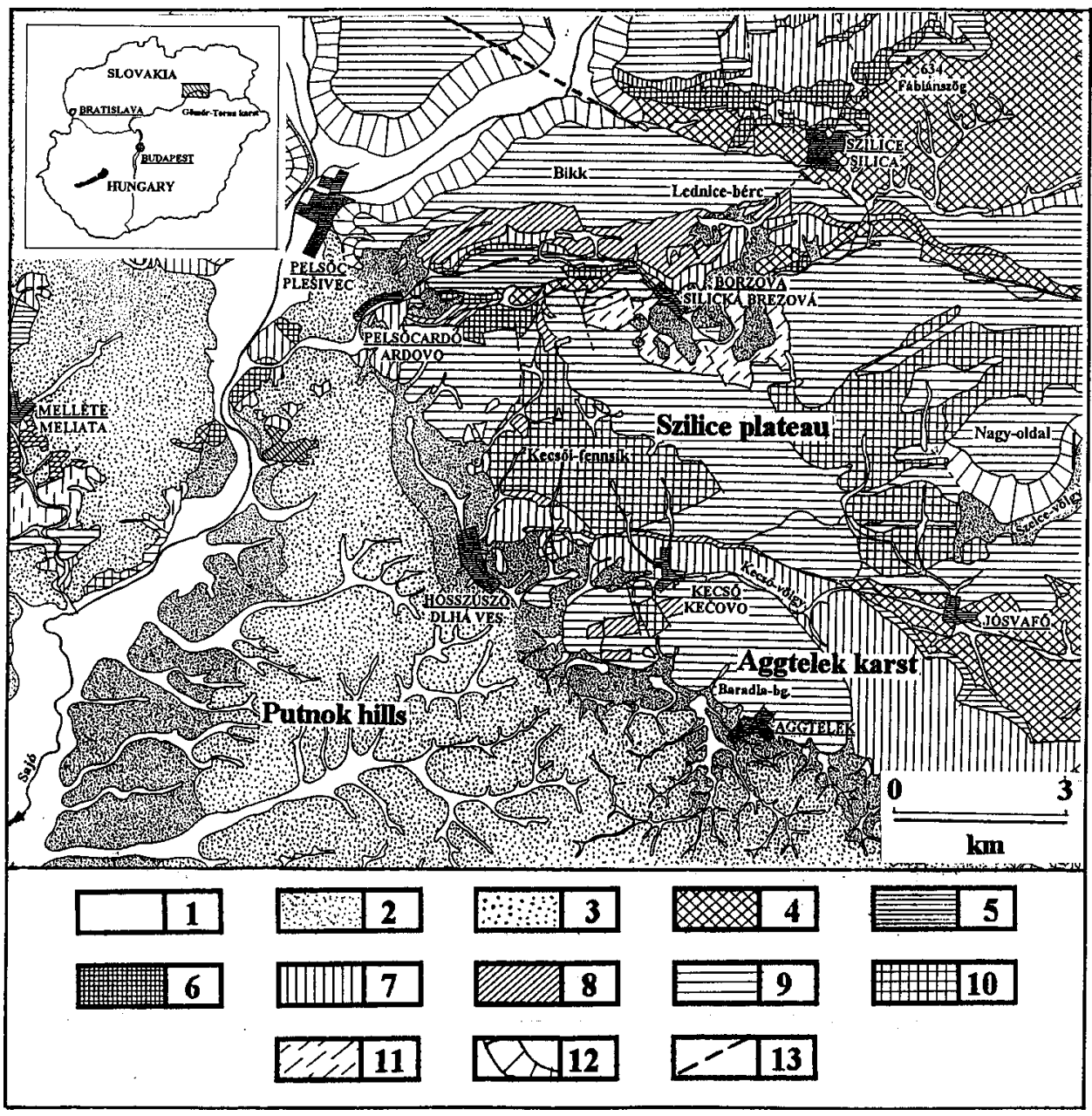

Fig. 1: The border of the covered and open karst between Pelsöc (Plešivec) and Aggtelek. (after Mello, J. 1997 and Less, Gy. et al. 1988):

1. aluvium, 2. Quaternary eluviums and proluviums, 3. Pliocene gravels and sands (Borsod Pebbles F.), 4. Lower Triassic shales and sandstone, 5. Gutenstein limestone, 6. Gutenstein dolomit, 7. Steinalm limestone, 8. Reifling limestones, 9. Wetterstein limestones, 10. Wetterstein dolomit, 11. Tisovec limestones. 
The Aggtelek karst together with the Szilice plateau is bordered by the covered karst towards the western direction. The boundary between the open and covered karst can be well defined in the line of Pelsőc (Plešivec) - Hosszúszó (Dlhá Ves) - Aggtelek, which essentially follows the main fracture line of Csetnek (Fig. 1). The surface development of the regions subdivided along the fracture line was similar until the end of the Tertiary, but was separated in the Pontian period. The territory falling N-NE from the fracture line gradually rose from the Pliocene, while on the part $\mathrm{W}$ from the fracture line a general sinking process began. Some parts of the Pannonic surface created by levelling falling $\mathrm{W}$ from the fracture line sank in a different degree. During the Pliocene (Jakál 1975), according to other scholars during the Pontian period (Less et al. 1988, Mello 1996) rough pebbled deposit (Poltar Pebble Formation, or Borsod Pebble Formation) was carried from the Vepor or Revuca mts. from NW to the territory and covered the lower limestone boards to a thickness of a few $10 \mathrm{~m}$. This pebble deposit can be well defined on the edge of the karst to about $400 \mathrm{~m}$ above sea level (scattered pebbles can be found at even $470 \mathrm{~m}$ ). On the E side of the Sajó valley on the contrary the pebbles form a coherent cover from Pelsőc to Égerszög.

Most part of the waters from the hilly region covered by pebbles, subdivided by "derosional" and erosional valleys is tapped by the branches of the Sajó (Szográgy, Csincsa, Uras or Lapsza, Szuha etc.). The valley heads of the water flows headward eroding from the Sajó, and during their headward erosion approached the edge of the karst from all directions but never reached it. An about 300-400 m high watershed back covered by pebbles rises a few hundred meters $\mathrm{N}$ from the karstic range and 1-2 km to the SE. The waters flowing down from the flat backs of the watershed partly flow W towards the valleys heading to the Sajó valley, and partly towards the edge of the karst, where they are swallowed by the swallow holes along the limestone band. The water in this way reappears in the springs of the Jósva valley, and flowing through the Jósva reaches the Bódva. The watershed between the Sajó and the Bódva thus stretches on top of these flat hills.

\section{THE DEVELOPMENT HISTORY OF THE KARSTIC WATER NETWORK ON THE SZILICE PLATEAU}

The earliest water-conducting valleys were situated along the main structural lines, the broken up anticlines and nappe fragments (Sajó-, Torna-, Ménes-, Kecső-, and Jósva-valley) (Mazur 1973, Jakál 1975, Fig. 1). The Jósva thus became the main tap of the Aggtelek, and Szilice plateau. Along the headward erosion of the Jósva it quickly reached the Jósvafö basin, which is the meeting place of water flows from different directions. From this period the surface waters flowing down from the Southern part of the Szilice plateau and from its neighbouring Aggtelek plateau are gathered by the Jósva.

The valley network of the territory between the Sajó and Bódva rivers started to develop first on the karstic plateaus. The ancient water network of the Szilice plateau was formed on the pebble, tuff and red clay cover deposits. The earliest water flow directions were indicated by the above mentioned structural directions. During the Ponthian period from the Kecső plateau, at that time still belonging to the covered Szilice plateau, the water flows followed the slope of the surface and ran down in a $S$ or SW direction, and were connected to the Jósva or to the main river of the neighbouring Gömör basin, the Sajó (Fig. 2). I drew the contemporary water network according to the structural-geological 


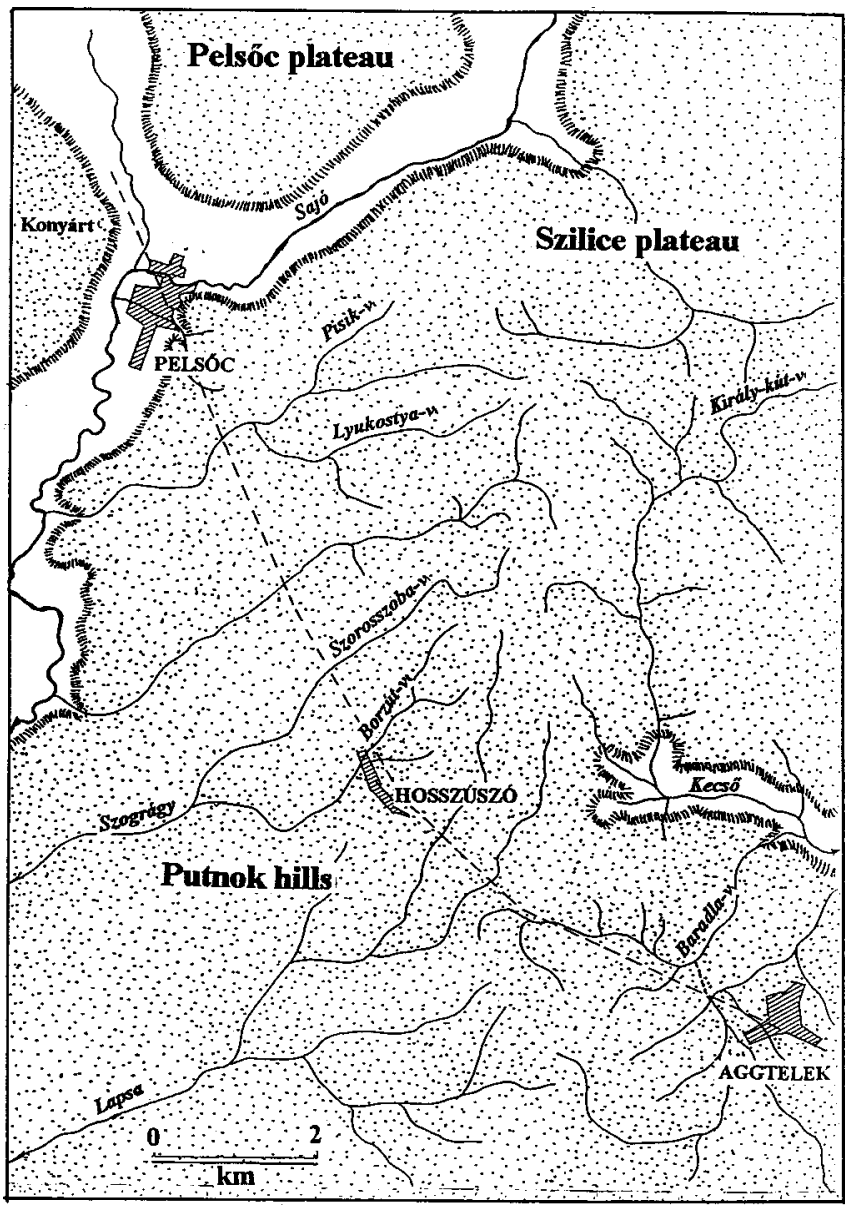

Fig. 2: The reconstructed water network of the Aggtelek karst and the bordering Szilice plateau during the Ponthian period. construction, the direction of the underground water flows and the position of the valleys with a row of dolines.

The Szilice plateau connected to the cutting in and broadening of the valleys gradually became exhumed, its cover deposits became thinner and were carried down. The covered karst was changed to open, or partly covered, exhumed karst. With the exhumation of the plateau the water flows were bathycaptured, the surface water network fell apart (Fig. 3). Surface water flows with periodical or permanent water remained only on the surface of the karstic rocks and on the surface of the clay and pebble deposits accumulated on the bottom of the Borzova polje (Fig. 4) The water flow of the double divided northern basin of the Borzova polje is connected to the Fekete spring underground stream system issuing in the Sajó valley, the water flow arriving from the Király-kút valley along with the accumulating waters of the southern basin of the Borzova polje feed the Kecső spring issuing on the southern edge of the Szilice plateau (Fig. 3). The big amount of water which arrives at the southern part of the polje at the time of floods is swallowed by the Büdös-tó swallow hole situated under the rocky mountain side forming the Southern border of the polje. A few $10 \mathrm{~m} \mathrm{~W}$ from the Büdös-tó hole is an abandoned swallow hole in which the mouth of the Milada cave opens, whose underground stream collects the waters disappearing in the surface holes and conducts it towards the Matilda cave (Fig. 4). The waters flowing on the edge of the karst basin continue towards the S; in its course it appears at the bottom of the Feneketlen-Lednice and finally reaches daylight at the Kecső spring.

The most interesting valley with a row of dolines on the Szilice plateau is situated between the 


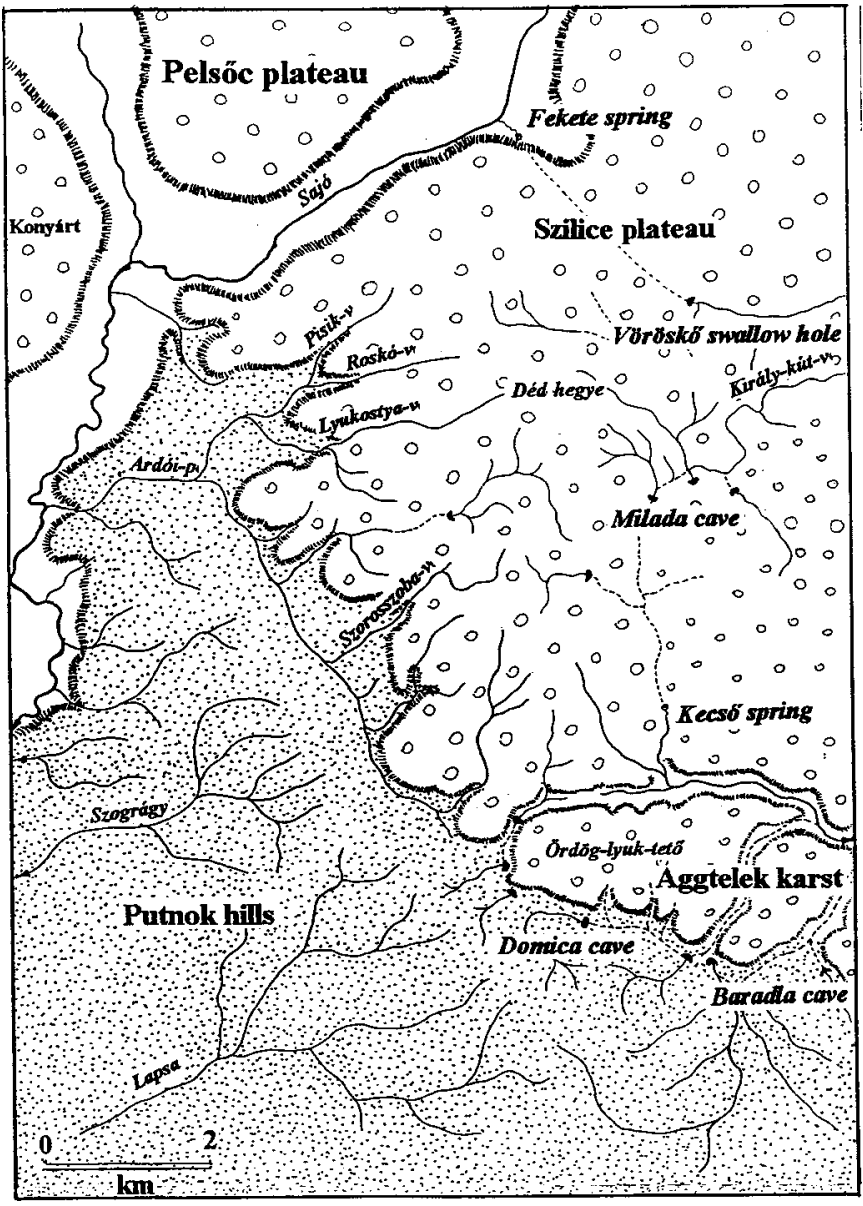

Fig. 3: The surface water network fell apart and was deepened with the rise and exhumation of the karstic plateaus (beginning of the Pleistocene). southern valley of the Borzova polje and the Kecso valley (Photo 1), which was formed through the bathycapture of the water flow of an earlier erosion valley. The large dolines of the row between the Borzova polje and the Kecső valley on the western edge of the Kecsö plateau, line up on the bottom of a deep, cut in valley, which is divided from the neighbouring peaks by steep slopes. The saddles dividing the dolines from each other loose height towards the $S$, in the direction of the previous decline from 446 to $427 \mathrm{~m}$. In the place of this row of dolines earlier a water conducting valley was situated which led the waters of the Borzova basin towards the $S$, until its limestone and dolomite cover deposits were thick enough for the water system to develop on its surface. With the thinning of the cover deposits the water started to infiltrate into the depths, which was followed by bathycapture. Today's surface is the result of a three

phased bathycapture, which is supported by the two dolines between the opening between the Matilda cave's swallow hole and the entrance of the undeveloping valley. With the bathycapture of the water flow the valley dried out and its deepening stopped. From this period the water disappearing in the above mentioned swallow hole flows as underground stream towards the Kecső spring. In the meanwhile, in the bottom of the abandoned dry valley dolines are formed. The row of dolines formed in the valley was transformed into a hanging valley, its bottom, which was in most cases preserved in the saddles between the dolines is higher than the active water conducting valley sections in the bottom of the Borzova polje $(416 \mathrm{~m})$, near the swallow hole and in the environments of the Kecső spring (342 m). 


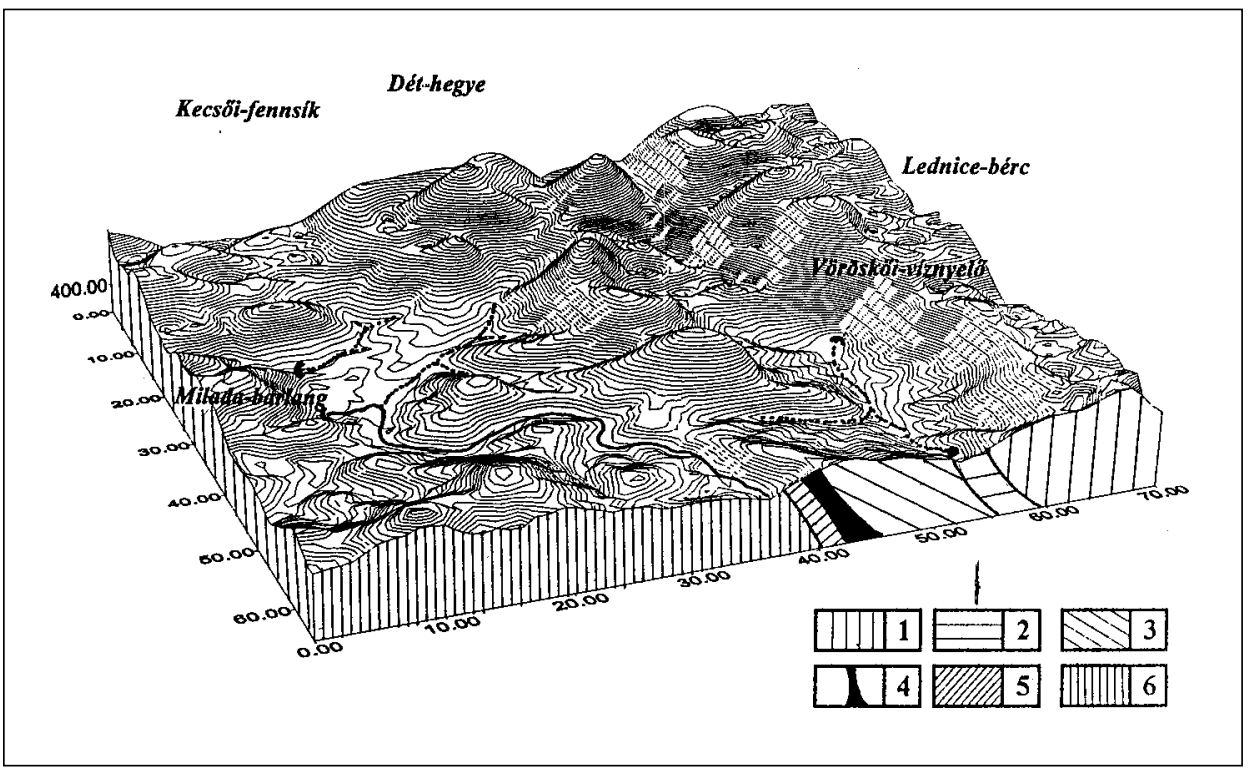

Fig. 4: The surface water network of the Borzova polje (Szilice plateau):

1. Wetterstein limestones, 2. Reifling limestones, 3. Steinalm limestones, 4. Lower Triassic shales and sandstone, 5. Gutenstein limestones and dolomit, 6. Upper Triassic limestones.

We know only smaller sections of the above mentioned underground stream's gallery system yet. The longest known part from the side of the swallow hole is the Milada cave where the stream can be followed some $800 \mathrm{~m}$ through the underground passages and rooms, where it ends in a siphon lake. We can meet the underground stream in the Matilda cave as well, but it is also interrupted by a siphon. Shortly afterwards it appears again in the deepest abyss of the Haragistya plateau, in the bottom of the so-called Bottomless-Lednice (Feneketlen Lednice) (Photo 2).

\section{THE DEVELOPMENT OF THE VALLEY SYSTEM OF THE AGGTELEK KARST AND THE NEIGHBOURING COVERED KARST}

The valleys of the hills falling between the Sajó and the Bódva rivers (Putnok hill range) started to develop in a later phase as the valleys of the karst. This was verified in the northern territory of the hill range bordered by the karst and covered by pebbles, in the vicinity of Aggtelek, where valley formation started during the Pontian-period (Mello 1996) or on the limit of the PliocenePleistocene-period (Less 1998), after the accumulation of the pebble material brought by the rivers flowing from the NW took place. Because of the fact that this territory lies the furthermost from the main river valleys (Sajó, Bódva) it probably took a lot of time before the side valleys (Lapsza, Csincsa, Szuha, Csörgős, Telekes-stream) headward eroding from the main river branch reached the pebbled surface neighbouring the karst (Fig. 1). 
János Móga: Reconstruction of the development history of karstic water networks on the southern part of the Gömör-Torna...

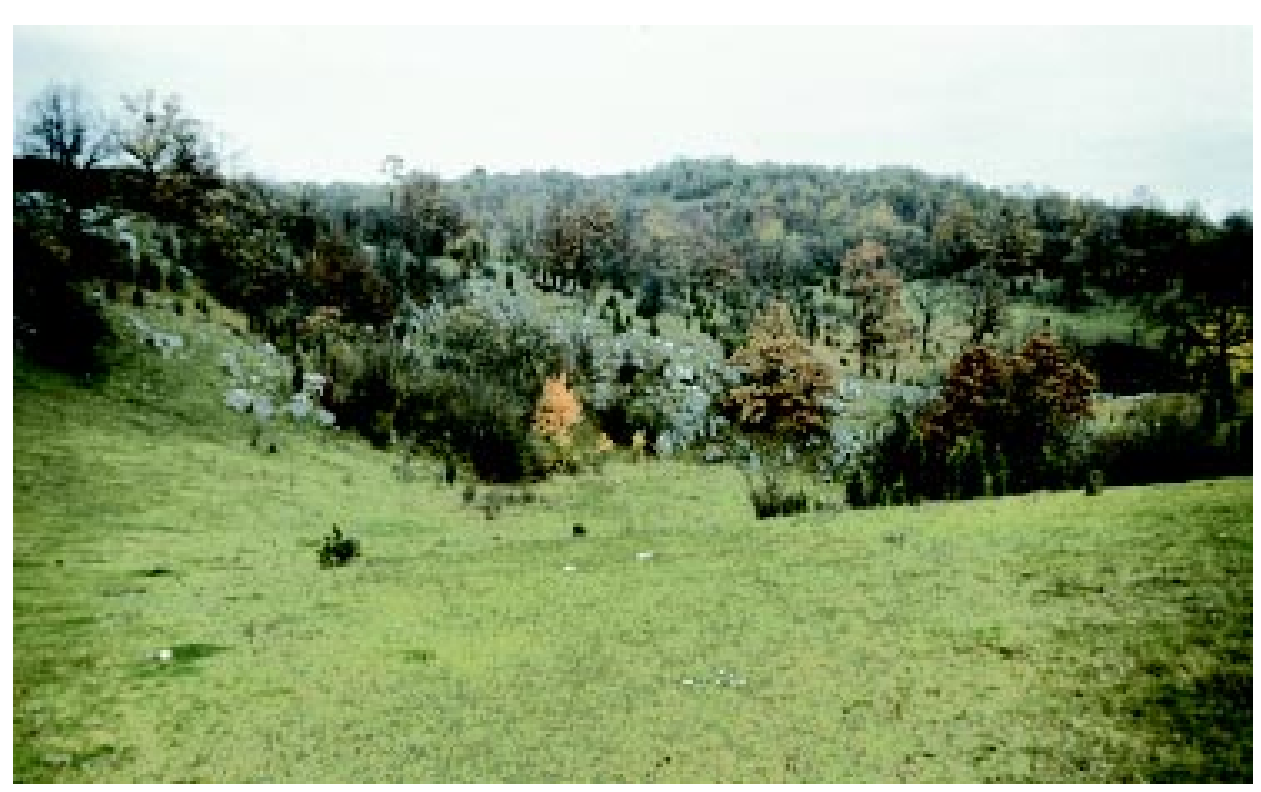

Photo 1: Series of dolinas on the Szilice plateau.

Photo 2: The Bottomless Lednice.

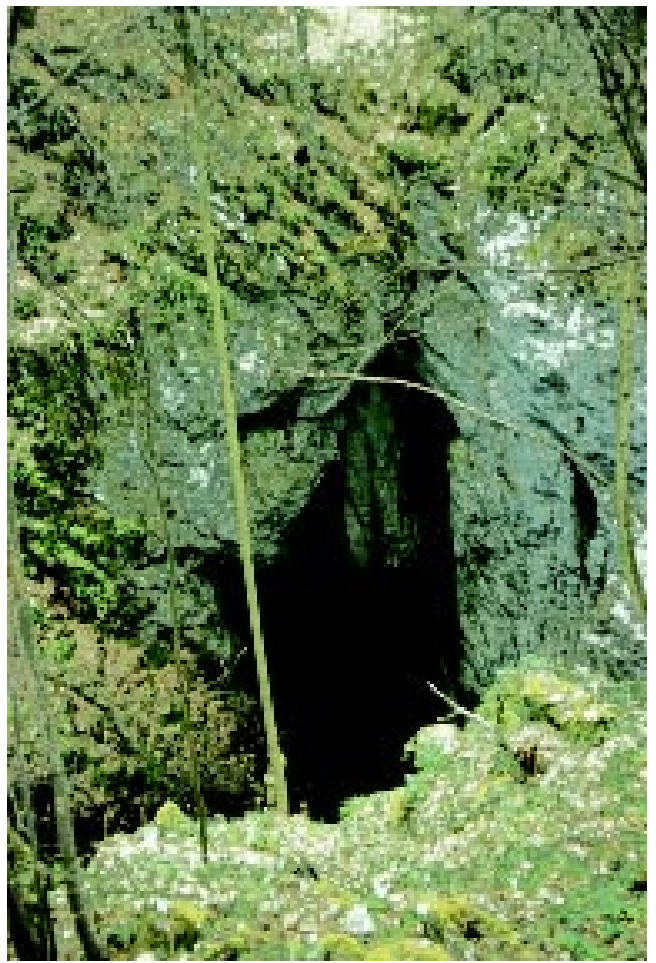




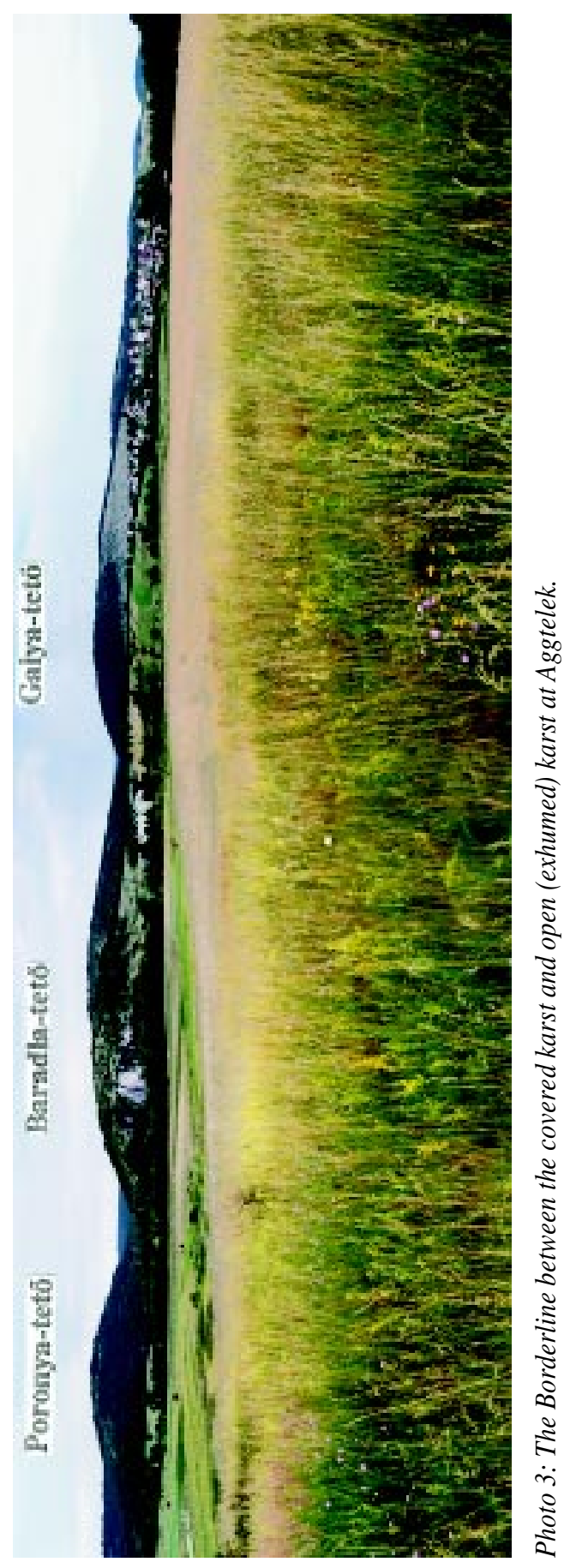


At the end of the Pliocene or in the early Pleistocene (Láng 1955), after the accumulation of the Poltar pebbles (Borsod pebbles) the formation of today's valley network started, which was directed on the western and southern part of the hilly region towards the Sajó, while on the eastern part towards the Bódva. The cutting in of the valleys and the gradual headward erosion of the valley heads approached the boundary of the karst plateau from every direction, where however by that time the Jósva valley had developed between the structural boundary of the Aggteleki karst and the Szilice plateau and drew to itself the surface water flows (Fig. 1).

Before the Roman structural movements the covered karst overlaid by pebbles and the surface lying near to the erosion base of the Aggtelek, and Szilice plateau were situated along similar heights above sea level, so the periodical water flows could cross the karst from the pebbled backs without any particular difficulty (Fig. 2). The valleys with a row of dolines developed from the above mentioned dry valleys can be recognised in a number of places in the lower ranges of the Aggtelek karst. Jakucs (1971) called attention to the fact that every water flow valley starting from the covered karst and ending in a swallow hole situated along the karst edge continues in a valley with a row of dolines in the direction of the Kecső, or the Jósva valley (Baradla, Mész, Hideg valley), and they give evidence about the earlier erosional phase of valley evolution (Fig. 3) (Photo 3).

Under the Roman-period the Szilice plateau and the territory of its neighbouring Aggtelek karst rose again. This emergence however did not effect, or only in a differentiated sort of way the territory falling $\mathrm{E}$ from the Csetnek fracture. In this way, in a short time about a $100 \mathrm{~m}$ of level difference was formed between the surface covered by pebbles and the karstic backs. From the surface of the rising karst plateaus gradually the pebble deposits, the tufs and the red clay etc., which have settled down during earlier geological periods were abraded. The exhumation of the karst plateaus took place. The water system of the karst was transformed or ceased with the bathycapture of the earlier water flows. The evolution through water erosion of the earlier water conducting valleys stopped. The corrosion processes started by the infiltrating waters in the drying up valleys slowly changed the surface and the earlier valleys were gradually transformed into valleys with a row of dolines.

The rising of the plateaus was pursued by the cutting in of the valleys developing on the impermeable slate zone anticlines, and so they could still preserve their water collecting activity, but instead collecting the waters of the drying out surface water flows of the dry subordinate valleys, they tapped the underground waters of the neighbouring karstic plateaus.

The short erosion valleys running down from the pebbled backs of the covered karst neighbouring the Aggtelek plateau still followed the direction of the limestone territories, but could not find an outflow towards the Jósva valley through the surface of the higher risen limestone bend. The water infiltrating at the border of the karst reached the many small springs of the Kecső, and Jósva valley through the crack system of the limestone The water filtration in the depths gradually widened the crack system of the rocks, and found outflow more easily. When the hollow network was wide enough, the underground water flows carried with them quartz pebbles from the neighbouring non karstic territories in a larger quantity, which enabled the underground hollow network to grow faster. The mechanical wearing off and erosional effect of the quartz pebbles drifted by water was emphasised first by L. Jakucs. He stated the earliest that the shallow beds of the surface water flows running towards the karst plateaus (Bába, Nagy-Ravasz hole) end up at the dolines, but the earlier abandoned, dried out valleys, or dry valleys which developed into valleys with a row of dolines continued in that direction where the earlier water flows before their bathycapture found way. He 




Fig. 5: The dried out valleys after the rise of the Roman phase cross the karst zone of the Aggtelek karst as doline line valleys (series of dolines).

observed that the caves with streams, lying under the karst plateaus are primarily formed through erosion and are essentially the underground continuation of the valleys of surface water flows (Jakucs 1956, 1971).

\section{THE DEVELOPMENT OF THE HOSSZÚSZÓ BORDERPOLJE}

On the northern part of the covered karst, between Hosszúszó and Pelsőcardó, today's water system was formed in several phases. During the Roman uprisal, on the boundary of the covered and open karst, under the step like edge of the Szilice plateau, a shallow structural depression developed, which drew to itself the water flows originating from higher territories, and changed their course in a NW direction. The water flows arriving from the Szilice plateau reached the Sajó valley turning westwards at the foot of the Nagy-hegy or Ardó mount, which was still half buried at that period. (Fig. 2).

With the gradual cutting in of the water flows, the carrying down of the pebble cover, the environment of the Ardo mt. was exhumated. With the thinning of the pebble cover the crack system of the buried limestone block tapped more and more the water flow of the karst edge valley. With the development of dolinas at the foot of the Ardó mount the surface drainage of the valley ceased and a sub surface drained horizontal basin, the Hosszúszó borderpolje was formed (Jakál 1975) 


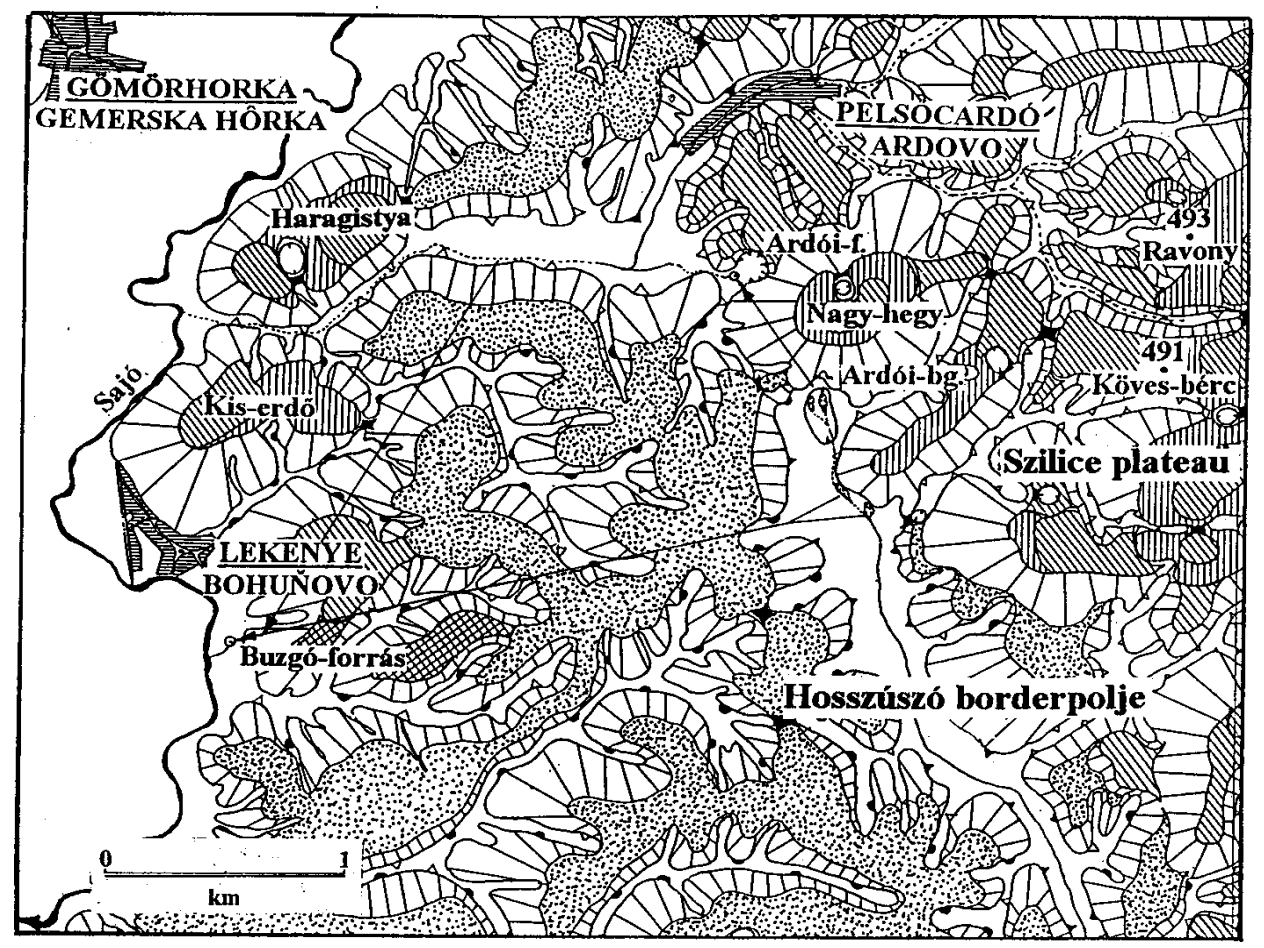

Fig. 6: The Hosszúszó borderpolje.

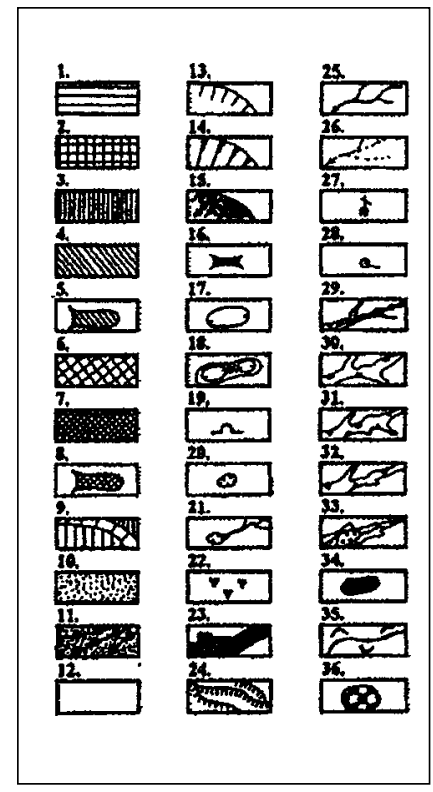

Legend to the Figurs 5. and 6.

Gömör-Szepes Ore mountain - 1. intervalley back, 2. summit of the intervalley back, Gömör-Torna-karst - 3. karst plateau or intervalley back developed on karst rocks, 4. the higher back of the karst plateau or the summit of the intervalley back (on karst rocks), 5. the resting point of the intervalley back (on karst rocks), 6. intervalley back developed on non-karst rocks, 7. the summit of the intervalley back developed in non-karst environment, 8. the resting point of the intervalley back on non-karst rocks, 9. enclosed basin of the karst plateau, 10. pannonian-pontian sediments, 11. alluvial fen, 12. alluvium, 13. slope, 14. the edge of the plateau, heavy slope, 15. rocky mountain side, 16. saddle, 17. dolina, 18. twin dolinas, uvala, 19. cave, 20. shaft, 21. ponor, swallow hole, 22. karrenfield, 23. village, 24. quarry, 25. permanent waterflow, 26. periodical waterflow, 27. well, 28. karst spring, 29. erosion valley, 30. derosion valley, 31. erosion and derosion valley, 32. dry valley, 33. swampy valley bottom, 34. lake, 35. oxebowl lake, 36. travertine. 
(Fig. 6). The Western border of the polje lies on the watershed peaks of the hill range covered by pebbles and slashed by erosional-derosional valleys, its eastern border coincides with the surfacing of the limestone and the dolomite, but its water collecting territory expands until the edge of the karst plateau by the connecting $2-3 \mathrm{~km}$ long dry valleys.

The small rivulet on the karst edge valley starts at Hosszúszó, collects the waters flowing from the pebbled backs of the hills, and the periodical waters of the neighbouring dry valleys and leads them to the swallow holes lying at the foot of the Nagy mountain of Ardó. At the bottom of the polje widening before the Nagy mountain 4 swallow holes open, 2 at the foot of the mountain, and 2 a bit further away (Fig. 6). The water of the stream flowing at the bottom of the polje, at times of low water level disappears in the further swallow holes. According to the tracing experiments of Orvan (1979), we know that the water disappearing here flows through the galleries of the covered karst towards the Sajó valley and reaches daylight in the Buzgó spring at the border of Lekenye.

The water accumulated at times of snow melt, lasting rain, spreads on the flat land lying on the part of the polje before the Nagy mountain. At such a time all swallow holes function, the 2 swallow holes situated near the foot of the Nagy mountain conduct its water into the galleries of the Ardó cave, which reaches daylight on the other side of the mountain lying nearer to Ardó, in a periodical spring (Ardó spring). The waters of the Ardó spring are united with the small stream arriving from Pelsőcardó, and crossing the covered karst continues its way towards the Sajó valley in its wide, flat bottomed valley as a normal, surface water flow. Its water however does not reach the Sajó valley because it infiltrates. The infiltrating water enters the crack system of the covered karst and emerges also in the Buzgó spring of Lekenye (Fig. 6). The tap of the Hosszúszó borderpolje is in both cases the Buzgó spring but the route of the water is different in low water level and in times of flood. The cave network of the Nagy mountain of Ardó can be acknowledged to be a peculiar case of bifurcation.

It is easy to imagine that the swallow holes around Ardó are not the starting points, but are only the continuation of a greater underground water network, which begins further E. The water disappearing in the swallow holes on the edge of the dolomite plateau already mentioned, and in the environment of the Pisik, Ezsdán, Lyukostya valley, and because of the water closing rocks found in the Ménes valley anticline and surfacing in the Borzova polje, can only move towards the $\mathrm{W}$ underground (Fig. 1). Only in the Sajó-valley cutting in deep (nearest the already mentioned Buzgó), where the water infiltrating from the above territories or flowing into the karst can appear.

\section{REFERENCES}

Csüllög, G. - Móga J. 1997: Geomorphology and drainage of the S-Gömör-Torna karst region in view of an environmental hazard. Zeitschrift Geomorph. Suppl. Bd. 110. pp. 255-261.

Dénes, Gy. 1971: A fokozatosan lepusztuló vízzáró takaró szerepe az exhumálódó karszt morfológiai fejlődésében. Karszt és Barlang 1. pp. 5-8.

Ford, D. C.\& Williams, P. W. 1992: Karst Geomorphology and Hydrology. Chapman \& Hall, London, $601 \mathrm{p}$.

Gams, I. 1977: Towards the Terminology of the Polje. Proceedings of the 7th International Speleological Congress, Sheffield, pp. 201-202.

Grill, J. 1989: Az Aggtelek-Rudabányai-hegység szerkezetfejlődése. MÁFI évi jel. 1987-ről, pp. 411-431. 
Hevesi, A. 1984: Karsztformák kormeghatározásáról és mészkőhegységeink újharmadidőszak végijégkori arculatának megrajzolásában játszott szerepükről, a Bükk hegység példáján. Földr. Ért. 33. 1-2. pp. 25-36.

Hevesi, A. 1986a: A Bükk felszínfejlődése és karsztja. Kandidátusi értekezés. Budapest MTA FKI. $187 \mathrm{p}$.

Hevesi, A. 1986b: Hidegvizek létrehozta karsztok osztályozása. Földr. Ért. 35. 3-4. pp. 231-254.

Jakál, J. 1975: Kras Silickej Planiny. Vyd. Osveta 145 p.

Jakál, J. 1989: Entwicklungsetappen des Karstreliefs der Westkarpaten. Carpatho-Balcan Geomorphological Comission Proceedings, Debrecen, pp. 33-42.

Jakucs, L. 1951: Vízföldtani megfigyelések a Gömöri-karszton, Földt. Közl. pp. 442-445.

Jakucs, L. 1956: Adatok az Aggteleki-hegység és barlangjainak morfogenetikájához. Földr. Közl. 80. 1. pp. 25-39.

Jakucs, L. 1968: Szempontok a karsztos tájak denudációs folyamatainak és morfogenetikájának értékeléséhez. Földr. Ért. 17. 1. pp. 17-47.

Jakucs, L. 1971: A karsztok morfogenetikája. Akadémiai kiadó, Budapest, 310 p.

Jakucs, L. 1977: A magyarországi karsztok fejlődéstörténeti típusai. Karszt és Barlang 1-2 pp. 1-16.

Láng, S. 1955: Geomorfológiai tanulmányok az Aggteleki karsztvidéken. Földr. Ért. 4. 1. pp. 1-17.

Less, Gy. 1998: Földtani felépítés. In: Az Aggteleki N. P. Mezőgazda, Budapest, pp. 26-66.

Less, Gy. et al. 1988: Az Aggtelek-Rudabányai-hegység fedetlen földtani térképe. MÁFI.

Mazur, E. 1973: Slovensky Kras. Regionalna fyzikogeografická analyza. Spec. Iss. of the VI. Int. Spel. Congr. in CSSr, 117. p.

Mello, J. 1996: Geologická mapa Slovenského krasu. Geologická služba Slov. Rep. Bratislava.

Mello, J. 1997: Vysvetlivky ku geologickej mape Slovenského krasu 1 : 50 000. Vyd. Dionýza Štúra, Bratislava, 255 p.

Orvan, J. 1979: Hydrogeologické pomery krasovej vyvieračky Buzgó v Bohúňové, Slovenskej kras. pp. 77-84.

Rozloûnik, M. - Karasová, E. 1994: Slovenský kras. Osveta, Banská Bystrica, 477 p.

\section{REKONSTRUKCIJA RAZVOJA REČNE MREŽE V JUŽNEM DELU KRASA GÖMÖR-TORNA NA PODLAGI PORUŠENIH JAM IN POVRŠINSKIH OBLIK}

\section{Povzetek}

Avtor razlaga razvoj kraškega površja Gömör-Torna (na madžarsko-slovaški meji) od terciarja do danes. Kot večina krasa v Karpatih in v karpatskem bazenu, je bilo tudi to ozemlje v terciarju prekrito (pokopano) z vododržnimi sedimenti. Gre za prehodno ozemlje med Slovaškim Rudogorjem in panonskim bazenom. Reke, ki so s tega gorovja tekle v panonski bazen, so prečkale kraško ozemlje. Danes predstavlja planota Gömör-Torna goli kras, zahodno od črte Plešivec - Dlhá Ves - Aggtelek pa je pokriti kras. Na planoti je mogoče slediti razvoju od pokritega do odprtega (golega) krasa in vpliv procesov zakrasevanja na površinske oblike in na smer podzemeljskega odtoka. Avtor je podrobneje preučil razvoj površja in podzemeljske vodne mreže ter na podlagi morfoloških oblik, ki jih je izdelala voda, ugotovil enakomerno zniževanje vodnih tokov. Podrobneje je obdelan kras 
na Silicki planoti in posebej razvoj sistema dolin na agteleškem krasu in na pokritem krasu v njegovi soseščini. Posebno poglavje je posvečeno robnemu polju Hosszúszó. Opirajoč se na skromne ostanke epigenih dolin, ki so bile tako v sedimentnem pokrovu kot v samem apniškem površju, na sledi nekdanjih ponorov v dnu dolin in na opuščene podzemeljske prevodnike (jame) iz zgodnejših faz razvoja, je avtor rekonstruiral smeri odtoka z obravnavanega kraškega ozemlja na prehodu med pokritim in golim krasom. 